\title{
PARTICULATE AND SOLUBLE ANTIGENS OF MICRO- POLYSPORA FAENI IN EXPERIMENTAL ALLERGIC ALVEOLITIS OF THE MOUSE
}

\author{
W. BLYTH AND VIOLET E. WARDROP \\ Experimental Mycoses Unit, Department of Botany, University of Edinburgh, \\ Mayfield Road, Edinburgh EH9 3JH, Scotland
}

\section{Plates XIX AND XX}

Healthy farmers often possess strong precipitating antibodies to Micropolyspora faeni, the organism most commonly causing farmer's lung disease (Pepys et al., 1963). In individuals showing clinical signs of the disease, precipitating antibody can sometimes, but not always, be demonstrated (Pepys and Jenkins, 1965; Grant et al., 1972; Edwards, Baker and Davies, 1974) and it is therefore clear that the presence of antibody is proof of exposure to antigen rather than evidence of disease. Culture filtrates and mycelial extracts from $M$. faeni have been shown to contain numerous antigens when tested against strongly precipitin-positive sera (Fletcher, Rondle and Murray, 1970; Hollingdale, 1974). The role of such antigens in the induction of extrinsic allergic alveolitis is little understood, and although farmer's lung has been widely regarded as the result of an Arthus reaction (Type III of Gell and Coombs, 1968), components of other hypersensitivity reactions such as Type I, Type II and particularly Type IV (Seal et al., 1968) have also been implicated.

Respirable dust from hay and grain upon which $M$. faen $i$ has grown may carry an array of soluble antigens derived from metabolism, and particulate antigens in the form of mycelial fragments and spores. The following work investigates the effects of these antigens and their biochemical fractions on the development of allergic pulmonary disease in the mouse in relation to the types of hypersensitivity reaction involved.

\section{MATERIALS AND METHODS \\ Growth and harvesting of cultures}

A strain of $M$. faeni provided by Dr J. Lacey (Rothamstead Experimental Station, Harpenden, Herts.) was grown for 1, 4 or 6 weeks in liquid culture in Casein Hydrolysate Medium (Oxoid, CM 1). Litre flasks, each containing $250 \mathrm{ml}$ medium were placed in an orbital incubator in darkness at $50^{\circ} \mathrm{C}$. Cultures were also grown on half-strength nutrient agar for 1 week. After the addition of sodium azide to give a final concentration of $0.03 \%$ $(\mathrm{w} / \mathrm{v})$, culture filtrate was freed of mycelium by centrifugation for $20 \mathrm{~min}$. at $3000 \mathrm{~g}$ and room temperature). The culture filtrate (CF) was then clarified, concentrated and dialysed in an Amicon Stirred Cell Model 202 (Amicon Ltd, Lexington, Mass., USA) with DPO6 and UM2 filters. The final retentate was approximately one-fortieth the volume of the original $\mathrm{CF}$. Mycelium was washed twice in phosphate buffered saline $(0.137 \mathrm{M}$ sodium chloride in $0.067 \mathrm{M}$ phosphate buffer, $p \mathrm{H} \mathrm{7.0)}$ by centrifuging at $3000 \mathrm{~g}$ for $20 \mathrm{~min}$., and stored at $4^{\circ} \mathrm{C}$.

\footnotetext{
Received 14 Aug. 1976; accepted 24 Jan. 1977.
} 


\section{Preparation of antigens}

Particulate antigens. Four types of preparation were made as follows. (1) Live spores and mycelial fragments (LSM) were harvested in sterile saline from plate cultures and concentrations adjusted to $25 \times 10^{6}$ propagules per $\mathrm{ml}$. (2) Dead spores and mycelium (DSM) were obtained from liquid shake cultures grown for 1 week in Casein Hydrolysate Medium and killed by adding sodium azide to a concentration of $0.03 \%$; the material was then stored at $4^{\circ} \mathrm{C}$ as a suspension containing $25 \times 10^{6}$ propagules per $\mathrm{ml}$. (3) Defatted spores and mycelium (DFSM) were obtained from $15 \mathrm{~g}$ (wet weight) DSM by two $24 \mathrm{~h}$ treatments with $30 \mathrm{ml}$ of a $1: 1$ mixture of ethanol and ether, followed by two similar treatments with chloroform. Defatted propagules were recovered following decantation and evaporation of residual chloroform and were resuspended in sterile saline at a concentration of $25 \times 10^{6}$ per $\mathrm{ml}$. (4) Chloroform extracts (Chl) were evaporated to dryness and the insoluble substances suspended in sterile saline at a concentration of $23 \mathrm{mg}$ per ml by two 10-s periods of ultrasonication at $18 \mu \mathrm{m}$ peak to peak from a MSE 100-W Ultrasonic Disintegrator (MSE Ltd, Manor Royal, Crawley, Sussex).

Soluble antigens. Ethanol-ether extracts (EE) were evaporated to dryness. The watersoluble components were taken up in distilled water at a concentration of $25 \mathrm{mg}$ per $\mathrm{ml}$ and dialysed against running tap water for $72 \mathrm{~h}$. Total water-soluble extract (TWSE) consisted of equivalent proportions of culture filtrates and soluble antigens from mycelium grown for either 1 or 6 weeks in Casein Hydrolysate Medium. Mycelium was treated with three alternating cycles each of freezing and thawing followed by ultrasonication for $3 \mathrm{~min}$. at $18 \mu \mathrm{m}$ peak to peak. Soluble antigens were recovered in the supernate after centrifugation at $3000 \mathrm{~g}$ for $20 \mathrm{~min}$.

Fractions from preparative polyacrylamide-gel electrophoresis. Culture filtrate from cultures grown in half-strength nutrient broth for 1 week was separated by electrophoresis. A 2-ml sample was passed through a $7.5 \%$ polyacrylamide gel containing $6.0 \mathrm{M}$ urea in Tris-glycine buffer, $p \mathrm{H} 8.3$ in a Preparative Polyacrylamide Electrophoresis Apparatus, Mark II (Shandon Southern Instruments Ltd, Camberley, England). Electrode chambers contained

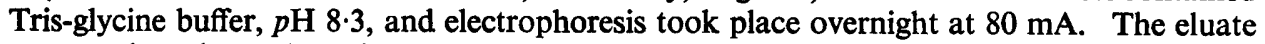
was monitored at $280 \mathrm{~nm}$ by means of a Pye Unicam SP500 Series 2 Spectrophotometer and collected in fractions of $3 \mathrm{ml}$ in an UltroRac 7000 Fraction Collector (LKB-Produkter AB, Sweden). Pooled fraction were concentrated to give a final volume of $0.2 \mathrm{ml}$ per tube. The fractions used were from tubes 11 to 18,19 to 35,36 to 50,51 to 57 and 58 to 70 .

The adsorbed fraction from affinity chromatography: Con. A-Sepharose. Fifteen-ml samples of concentrated culture filtrate from 1-week old cultures of the organism grown in Casein Hydrolysate Medium were passed through a $1.6 \mathrm{~cm} \times 12 \mathrm{~cm}$ column of Concanavalin A-Sepharose (Pharmacia Ltd, Uppsala, Sweden). The column was eluted with $0.067 \mathrm{M}$ phosphate buffer, $p \mathrm{H} 7.0$ containing $1.0 \mathrm{M} \mathrm{NaCl}$. Absorbance was monitored at $280 \mathrm{~nm}$ and 3-ml fractions were collected. To release bound polysaccharides and glycoproteins, the eluant was changed to borate buffer, $p \mathrm{H} 6.0$, containing $1.0 \mathrm{M} \mathrm{NaCl}$ (Kennedy and Rosevear, 1973) and finally to the borate buffer containing 1.0M $\alpha$-methyl-D-glucopyranoside (MGP) (Aspberg and Porath, 1970). For each tube fraction, total carbohydrate was estimated by the orcinol test for pentoses (Herbert, Phipps and Strange, 1971), protein as $\alpha$-amino acids by the ninhydrin method (Moore and Stein, 1948) and hexosamine by the Elson-Morgan reaction (Herbert et al., 1971). As the eluate from borate buffer alone was serologically negative, this intermediate step was subsequently omitted. The non-adsorbed material (Fraction I) was recycled until no more material was adsorbed by the gel and the eluates from borate buffer containing 1.0M MGP were then bulked (Fraction II) and passed through a $1.6 \mathrm{~cm} \times 40 \mathrm{~cm}$ column of Sephadex G25 to remove the MGP. Fraction II was concentrated by ultrafiltration through a UM-2 filter.

Fractions from affinity chromatography: Sepharose $4 B$ immunoadsorbents. Immunoglobulins precipitated from sera by ammonium sulphate (Heide and Schwick, 1973) were coupled to Sepharose 4B (Pharmacia Ltd, Uppsala, Sweden) by the cyanogen bromide (CNBr) technique as described by Cuatrecasas and Anfinsen (1971) and Molenaar, Müller and Pondman (1973). The immunoglobulins were obtained from human sera with pre- 
cipitating antibodies to extracts from $M$. faeni; they were from individuals with (FLD) or without (non-FLD) symptoms of farmer's lung disease. From an amalgamate of 10 culture filtrates, $0.5 \mathrm{ml}$ was added to the $0.9 \mathrm{~cm} \times 15 \mathrm{~cm}$ columns. The filtrates were from cultures grown at $50^{\circ} \mathrm{C}$ for 1,4 and 6 weeks in nutrient broth and Casein Hydrolysate Medium. The columns were successively eluted with $50 \mathrm{~mm}$ borate buffer $p \mathrm{H} 8 \cdot 0,3 \cdot 0 \mathrm{M}$ acetic acid, $6.0 \mathrm{M}$ guanidine $\mathrm{HCl}$ and $50 \mathrm{~mm}$ borate $p \mathrm{H} 8.0$. Recycling was continued until no more material was taken up, and the fractions obtained by the use of each buffer were bulked. Fractions were dialysed and concentrated by ultrafiltration before use in animal experiments, and analysed by immunoelectrophoresis with a composite human serum prepared from 17 precipitin-positive sera.

Fractions from preparative electrophoresis in agar. By means of modification of the method of Jonasson and Becker (1966), 0.3-ml aliquots of pooled tube fractions 11 to 50 obtained by preparative polyacrylamide-gel electrophoresis, as described above, were separated by electrophoresis in agar. The material to be separated was placed in a $2 \mathrm{~mm} \times$ $70 \mathrm{~mm}$ trough cut $10 \mathrm{~mm}$ from one end of a sheet of veronal buffered agar, $p \mathrm{H} 8.2,2 \mathrm{~mm}$ in depth on an $80 \mathrm{~mm} \times 100 \mathrm{~mm}$ glass plate. Electrophoresis was carried out at $20 \mathrm{~mA}$ for $3 \mathrm{~h}$ towards the cathode to allow effective separation of components. A strip of agar, $5 \mathrm{~mm}$ wide, was then cut out from the centre of the plate and transferred to one side of a glass slide. Molten agar was poured on to the remainder of the slide and allowed to set to give a layer $2 \mathrm{~mm}$ deep adjacent to the strip. A $2 \mathrm{~mm} \times 65 \mathrm{~mm}$ trough cut in the layer $2 \mathrm{~mm}$ from the strip was filled with composite farmer's lung serum. The slide was incubated at $37^{\circ} \mathrm{C}$ for $48 \mathrm{~h}$ to allow development of arcs of precipitation. During this time the electrophoresis plate was frozen at $-20^{\circ} \mathrm{C}$. After noting the position of precipitin arcs, corresponding frozen bands of agar were cut out from the plate and their antigenic contents released by thawing. Three fractions, $\mathrm{L}, \mathrm{M}$ and $\mathrm{N}$ (fig. $5 d$ ), were each concentrated to $0.6 \mathrm{ml}$ in an Amicon Ultrafiltration Cell, Model 10PA, with a UM-2 filter.

Dialysis and storage of antigenic fractions. Unless otherwise stated, all extracts were dialysed for $48 \mathrm{~h}$ against running tap water and stored at $-20^{\circ} \mathrm{C}$ before use.

\section{Serology}

Double diffusion and immunoelectrophoresis were carried out in 1.5\% Purified Agar (Oxoid, L28) containing veronal buffer, $p \mathrm{H} 8 \cdot 2$, and occasionally in cellulose acetate membrane (Celagram, Shandon Ltd). Immunoelectrophoresis was carried out according to Scheidegger (1955) and precipitin arcs were stained by $1 \%$ Ponceau S or Amido Black in $7 \%$ acetic acid. Antiserum was either human composite or that raised against TWSE of $M$. faeni in the rabbit.

\section{Animals and schedules of immunisation}

Mice. Eight-week old male and female albino Swiss mice were obtained from the Centre for Laboratory Animals, The Bush, Penicuik, Scotland.

Schedule of immunisation for the production of precipitating antibodies. Equal proportions of Freund's complete adjuvant (FCA) and antigen (TWSE) were mixed and emulsified. Mice were injected intraperitoneally with $0.2 \mathrm{ml}$ of the mixture and serum was obtained by cardiac puncture between the 40th and 63rd day (Herbert, 1963). Antibody response, measured by double diffusion in agar, was greatest at day 63 , and this period of immunisation was therefore adopted. A booster dose of $0.1 \mathrm{ml}$ antigen in FCA was given subcutaneously on day 63 and was followed 7 days later by intranasal inoculation with appropriate material.

Schedule of short-term immunisation for the production of delayed hypersensitivity. Each animal was given $0.1 \mathrm{ml}$ of TWSE in FCA intraperitoneally. Intranasal inoculations commenced on the 8th day when animals were precipitin-negative.

\section{Investigation of delayed hypersensitivity in precipitin-negative mice}

The bentonite granuloma test was carried out as recommended by Boros and Warren (1970 and 1973). Antigen-coated or uncoated particles were injected intravenously into 
precipitin-negative mice sensitised by treatment 8 days earlier with TWSE in FCA, or into unsensitised animals given saline in FCA. After a further 8 days, the animals were killed. In the lung sections prepared, 20 to 30 granulomata per treatment were measured.

Cutaneous reactions were studied by intradermally injecting dialysed TWSE into the shaven flanks of mice treated intraperitoneally with TWSE in FCA 8 days previously. Experiments were performed in parallel on unsensitised mice. Skin samples from both sensitised and unsensitised animals were excised and fixed in neutral formalin at intervals of $2,6,15$ and $65 \mathrm{~h}$ after injection, and were then processed for histological examination.

Intranasal inoculations. Materials were administered to mice under light anaesthesia in doses of four drops on day 1 and two drops on days 2 and 3, giving a total volume of $0 \cdot 2 \mathrm{ml}$. Animals were killed on day 4. For histological studies of cellular reaction in relation to time in precipitin-positive animals, a single intranasal inoculation preceded sacrifice at 6 or $24 \mathrm{~h}$. Control animals were treated with saline.

Numbers of mice. Groups of four or five animals were used as controls and for each schedule of treatment employed to assess bentonite granuloma formation, cutaneous reactions or the effects of intranasal inoculations.

Histology and serology. Mice were bled by cardiac puncture and, after testing against TWSE by double diffusion in agar, sera were stored at $-20^{\circ} \mathrm{C}$. Lungs were gently infused with neutral formalin by tracheal instillation and then removed for further processing and sectioning. Sections were stained with haematoxylin and eosin.

\section{Immunisation of rabbits}

Four rabbits were immunised by six intramuscular injections of $0.5 \mathrm{ml}$ antigenic extract in an equal volume of FCA, at weekly intervals. Two rabbits were treated with culture filtrate and two with soluble mycelial antigens of $M$. faeni. Equal volumes of each serum were bulked.

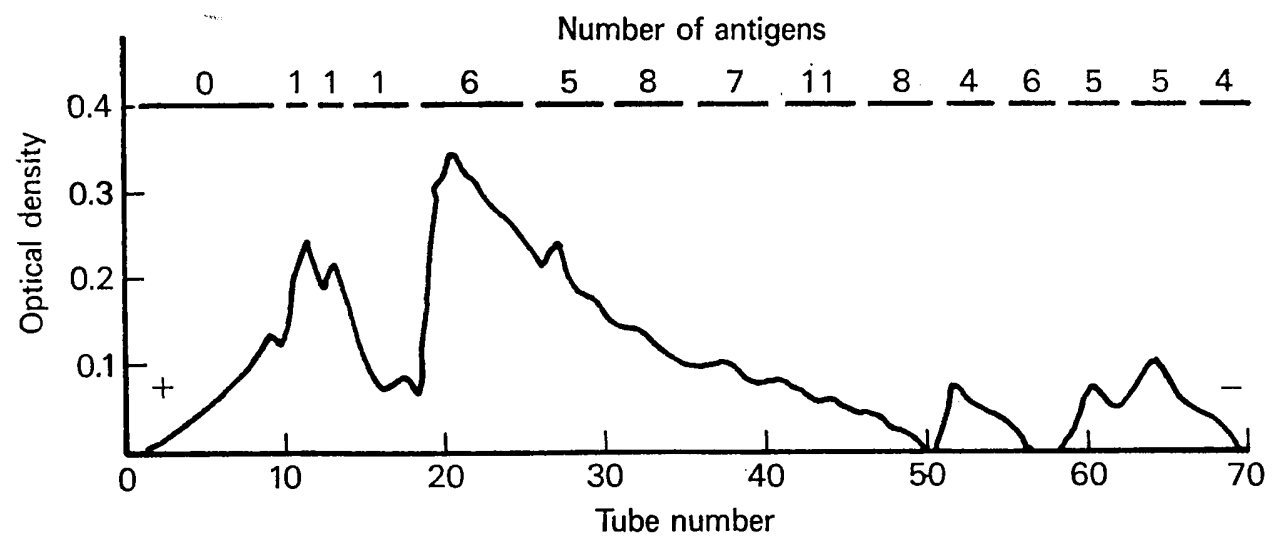

\begin{tabular}{r|c|c|c|c|c|}
\cline { 2 - 6 } Fraction & $11-18$ & $19-35$ & $36-50$ & $51-57$ & $58-70$ \\
\hline A & $2+$ & $3+$ & $2+$ & - & - \\
V & $2+$ & $2+$ & $2+$ & - & - \\
B & $2+$ & $2+$ & $2+$ & - & - \\
\cline { 2 - 7 }
\end{tabular}

FIG. 1.-The optical density at $280 \mathrm{~nm}$ of the eluate from preparative polyacrylamide-gel electrophoresis of a 7-day culture filtrate of $M$. faeni. Antigenicity and ability to induce alveolitis (A), perivasculitis (V) and peribronchiolitis (B) in precipitin-positive mice are indicated by a " plusminus" system. 
$\downarrow \mathrm{PO}_{4}, \mathrm{pH} 7.0+1 \mathrm{M} \mathrm{NaCl}$

(a)

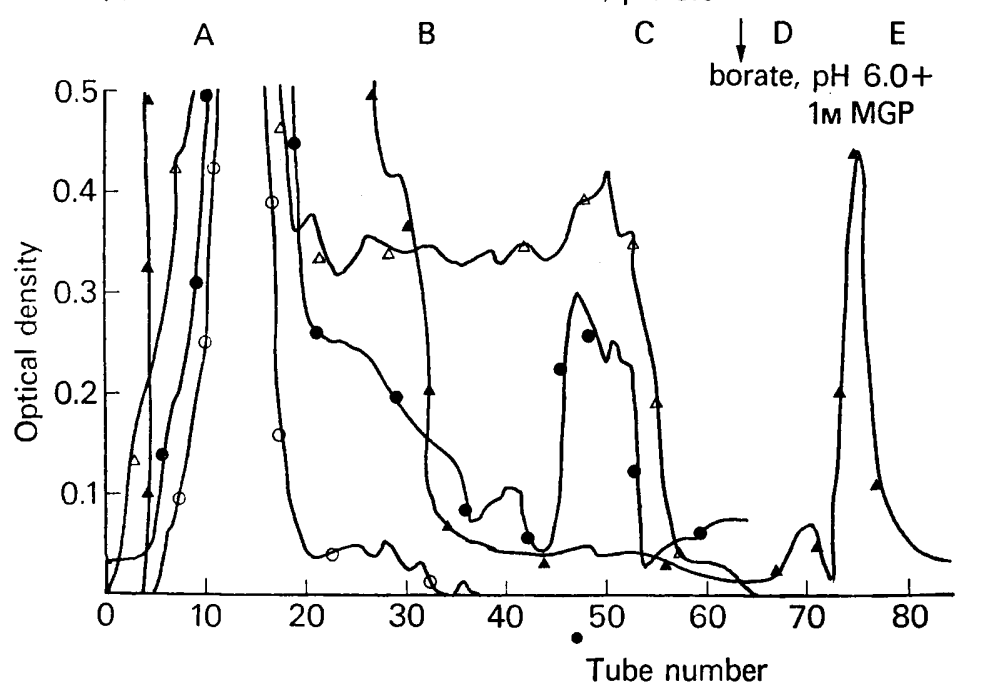

(b)

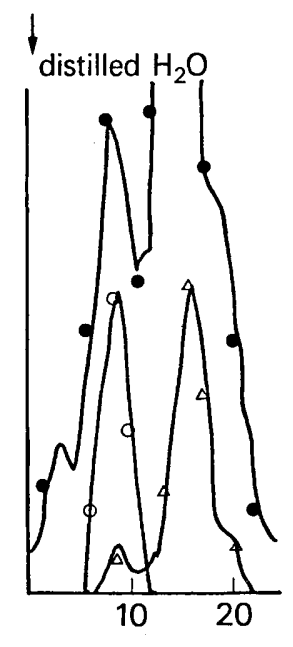

Fig. 2( $a$ and $b$ ).-The optical density at $280 \mathrm{~nm}$ (A) of the eluate from a 7-day culture filtrate of $M$. faeni chromatographed on Con A-Sepharose 4B $(a)$ and of the fraction desorbed by $\alpha$-methylD-glucopyranoside (MGP) passed through Sephadex G25 (b). Protein (ninhydrin method) $-\triangle-$; $0.20 \mathrm{OD}=0.645 \mathrm{mM}$ L-asparagine. Total carbohydrate (orcinol method) $-0-; 0.20 \mathrm{OD}=$ $30 \mu \mathrm{g}$ ribose. Hexosamine (Elson-Morgan method) $-\mathrm{O}-; 0.20 \mathrm{OD}=100 \mu \mathrm{g}$ glucosamine$\mathrm{HCl}$. The three areas A, B and C, and the two peaks (D and E) that occurred after the buffer was changed to borate $p \mathrm{H} 6.0$ containing 1.0M MGP, are referred to in the text.

\section{RESULTS \\ Preparative polyacrylamide-gel electrophoresis}

The numbers of arcs of precipitation resulting from double diffusion of preparative fractions against rabbit antiserum in cellulose acetate membrane are recorded in fig. 1. The fractions used in animal experiments were those with antigenic activity, i.e., the fractions between tubes 11 and 70 . Both antigenic activity and OD at $280 \mathrm{~nm}$ were taken into account and the fractions used in animal experiments were 11 to 18,19 to 35,36 to 50,51 to 57 and 58 to 70 .

\section{Biochemistry of Fractions I and II from affinity chromatography on Con A-Sepharose}

The carbohydrate, protein and hexosamine content of individual tube fractions recovered from Con A-Sepharose is recorded in fig. 2. For unbound or lightly bound substances eluted from the columns, three areas, A, B and C could be distinguished (fig. 2a). Area A gave peak values for all tests, area B was a plateau of low values and area $\mathrm{C}$, which followed the addition of borate buffer, showed a slight rise in both carbohydrate and protein values, but not in those of hexosamine. Antigen reacting with rabbit antiserum in cellulose acetate membrane was confined to tube fractions from area $\mathrm{A}$, where peak 


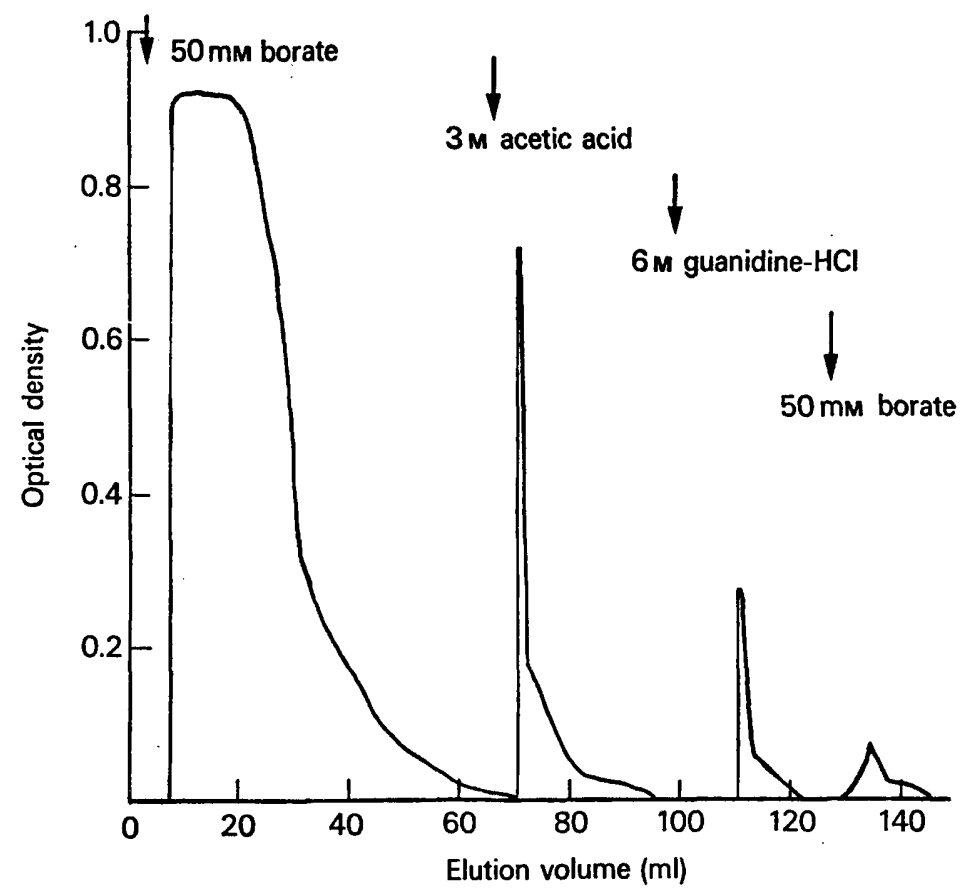

Fig. 3.-The optical density at $280 \mathrm{~nm}$ of the eluate from composite culture filtrates of $M$. faeni chromatographed on FLD immunoglobulins coupled to Sepharose 4B.

values were recorded for protein, total carbohydrate and hexosamine, and coincided with the bulk of pigmentation of the original culture filtrate. Of tube fractions subsequently bulked and concentrated four-fold, only fraction 20 to 25 , adjacent to the reactive part of area A, was positive. After changing the buffer to borate, $p \mathrm{H} 6 \cdot 0$, containing 1.0M MGP, the subsequent trace consisted of two peaks, D and E (fig. 2a). Each was desalted by passage through a column of Sephadex G 25 and material from peak D, although containing carbohydrate and protein, was negative for hexosamine. No antigens were detected, either in individual tube fractions or in bulked fractions concentrated 20 -fold. Material from peak E was eluted as two peaks (fig. $2 b$ ) of which the first alone contained hexosamine, and when concentrated 20 -fold was the only desorbed antigenic fraction (Fraction II). A bulked concentrate of areas A, B and $\mathrm{C}$ was recycled, omitting the use of borate buffer, $p \mathrm{H} 6 \cdot 0$, containing $1.0 \mathrm{M}$ $\mathrm{NaCl}$, until no more material was removed by borate buffer, $p \mathrm{H} 6 \cdot 0$, containing 1.0M MGP. The pooled fractions, desorbed by MGP, passed through Sephadex G25 and found to be antigenic (Fraction II), were concentrated and used for the intranasal inoculation of mice.

\section{Affinity chromatography on immunoadsorbent columns}

A trace typical of the chromatography of composite culture filtrate of $M$. faeni on FLD and non-FLD immunoglobulins coupled to Sepharose 4B by the 
cyanogen bromide $(\mathrm{CNBr})$ method is shown in fig. 3. Recycling of unadsorbed material produced similar traces with, as expected, a continuous removal of decreasing amounts of antigen from the original culture filtrate.

\section{Immunological lung damage in precipitin-positive mice}

Single intranasal inoculations with LSM, DSM or TWSE were followed within $6 \mathrm{~h}$ by a general infiltration of alveolar septa by inflammatory cells. Polymorphonuclear leucocytes predominated and some contained prominent eosinophil granules. Macrophages were scarce at this stage and rarely comprised $50 \%$ of the infiltrate (fig. $4 a$ and $b$ ). Slight peribronchiolitis and periarteriolitis occurred occasionally, but were not features of the histological pattern at this time. At $24 \mathrm{~h}$, histological examination showed that alveolar septa were extensively infiltrated by cells that were predominantly macrophages. Polymorphonuclear leucocytes were then scarce and lymphocytes prominent. Localised alveolar filling caused the formation of granuloma-like zones, very variable in size and number in any one lung lobe (fig. $4 c$ and $d$ ). The walls of arterioles were severely oedematous and diapedesis of cells resulted in a mixed exudate of lymphocytes, macrophages and polymorphonuclear leucocytes (figs. $4 d$ and 5a). Peribronchiolitis was also common and the lumina of some bronchioles were infiltrated with aggregates of polymorphonuclear leucocytes, macrophages and cell debris (figs. $4 d$ and $5 a$ ). Giant cells were not common, but when present were either mononucleate or multinucleate. Syncytial aggregates of enlarged mononucleate cells were observed in some instances but areas of haemorrhage were rare and minimal. Three successive daily intranasal inoculations of antigen resulted in the development of similar, but usually more severe, effects in the lungs of animals sacrificed $24 \mathrm{~h}$ after the final treatment. In the lungs of mice examined 4 or 8 days after the final inoculation, some bronchioles showed accumulations of mucus accompanied by sparse leucocytic infiltrates, and some metaplasia of bronchial epithelium was evident (fig. 5b). No fibrosis was observed. In rare instances a haemorrhagic pneumonia was observed (fig. 5c). Alveoli were filled with red blood corpuscles and polymorphonuclear leucocytes, many of which contained eosinophil granules. Periarteriolitis was prominent and was accompanied by a mixed cell exudate containing polymorphonuclear leucocytes, lymphocytes, macrophages and occasional plasma cells. Peribronchiolitis was much less in evidence although the lumina of many bronchioles contained plugs of mucus in which polymorphonuclear leucocytes and cell debris had accumulated. This effect was seen in mice given a booster dose of DSM and inoculated intranasally either with DSM or TWSE, and also in those given a booster dose of TWSE and inoculated intranasally with the guanidine- $\mathrm{HCl}$ fraction from the FLD immunoadsorbent column. In any treatment group not all animals were uniformly affected.

\section{Effect of particulate and crude soluble antigens}

Mice primarily immunised with TWSE and after 63 days given a booster dose of TWSE, DSM or DFSM were inoculated intranasally as shown in 
TABLE I

Lesions produced in precipitin-positive and precipitin-negative mice inoculated intranasally with test materials from $M$. faeni

\begin{tabular}{|c|c|c|c|c|c|}
\hline \multirow{3}{*}{$\begin{array}{l}\text { Mice inoculated } \\
\text { intranasally } \\
\text { with }\end{array}$} & \multirow{3}{*}{$\begin{array}{c}\text { Lesion } \\
\text { produced }\end{array}$} & \multicolumn{4}{|c|}{ Severity of lesions in } \\
\hline & & \multicolumn{3}{|c|}{$\begin{array}{l}\text { precipitin-positive mice that, before } \\
\text { intranasal inoculation, had received a } \\
\text { booster dose of }\end{array}$} & \multirow[t]{2}{*}{$\begin{array}{l}\text { precipitin-negative } \\
\text { mice }\end{array}$} \\
\hline & & TWSE & DFSM & DSM & \\
\hline TWSE & $\begin{array}{l}\mathbf{A} \\
\mathbf{B} \\
\mathbf{V}\end{array}$ & $\begin{array}{l}1+ \\
1+ \\
1+\end{array}$ & $\overline{-}$ & $\frac{3+}{1+}$ & $\begin{array}{l}3+ \\
2+ \\
2+\end{array}$ \\
\hline DFSM & $\begin{array}{l}\mathbf{A} \\
\mathbf{B} \\
\mathbf{V}\end{array}$ & $\begin{array}{l}\bar{z} \\
\bar{z}\end{array}$ & $\stackrel{ \pm}{ \pm}$ & $\bar{z}$ & $\frac{ \pm}{ \pm}$ \\
\hline DSM & $\begin{array}{l}\mathrm{A} \\
\mathrm{B} \\
\mathrm{V}\end{array}$ & $\begin{array}{l}3+ \\
1+ \\
1+\end{array}$ & $\overline{-}$ & $\begin{array}{l}3+ \\
1+ \\
1+\end{array}$ & $\begin{array}{l}\cdots \\
\cdots \\
\cdots\end{array}$ \\
\hline LSM & $\begin{array}{l}\mathbf{A} \\
\mathbf{B} \\
\mathbf{V}\end{array}$ & $\begin{array}{l}3+ \\
1+ \\
1+\end{array}$ & $\begin{array}{l}- \\
- \\
-\end{array}$ & $\begin{array}{l}3+ \\
2+ \\
2+\end{array}$ & $\begin{array}{l}3+ \\
1+ \\
1+\end{array}$ \\
\hline $\mathrm{EE}$ & $\begin{array}{l}\mathrm{A} \\
\mathrm{B} \\
\mathrm{V}\end{array}$ & $\begin{array}{l}2+ \\
1+ \\
2+\end{array}$ & $\cdots$ & $\cdots$ & $\begin{array}{l} \pm \\
\pm\end{array}$ \\
\hline Chl & $\begin{array}{l}\text { A } \\
\text { B } \\
\text { V }\end{array}$ & $\begin{array}{l}- \\
\overline{-}\end{array}$ & $\ldots$ & $\ldots$ & $\begin{array}{l}- \\
- \\
-\end{array}$ \\
\hline
\end{tabular}

$\mathrm{A}=$ Alveolitis; $\mathrm{B}=$ peribronchiolitis $; \mathrm{V}=$ perivasculitis. Other abbreviations are explained under Materials and methods.

Lesions are graded arbitrarily as: $3+$, severe; $2+$, moderate; $1+$, mild; \pm , minimal and sporadic.

table I with TWSE, DSM, DFSM, LSM, EE or Chl. Mild to severe alveolitis resulted in all groups of mice except those given DFSM or Chl. Perivasculitis and peribronchiolitis followed much the same pattern of distribution as alveolitis. Neither primary immunisation alone, nor that followed by a boost with TWSE resulted in lung abnormalities. No effect was seen in fully immunised mice after intranasal inoculation with saline.

Effect of fractions from preparative polyacrylamide-gel electrophoresis. As may be seen in fig. 1, alveolitis, perivasculitis and peribronchiolitis were present in mice treated with fractions 11 to 18,19 to 35 and 36 to 50 . Of the three fractions, 19 to 35 was the most effective in provoking alveolitis. Fractions 51 to 57 and 58 to 70 induced no abnormalities.

Effect of the fraction from affinity chromatography: Con A-Sepharose. Alveolitis, perivasculitis and peribronchiolitis occurred in mice inoculated intranasally with Fraction II (table II), suggesting a correlation between biological activity and glycoprotein, as measured by hexosamine content. 

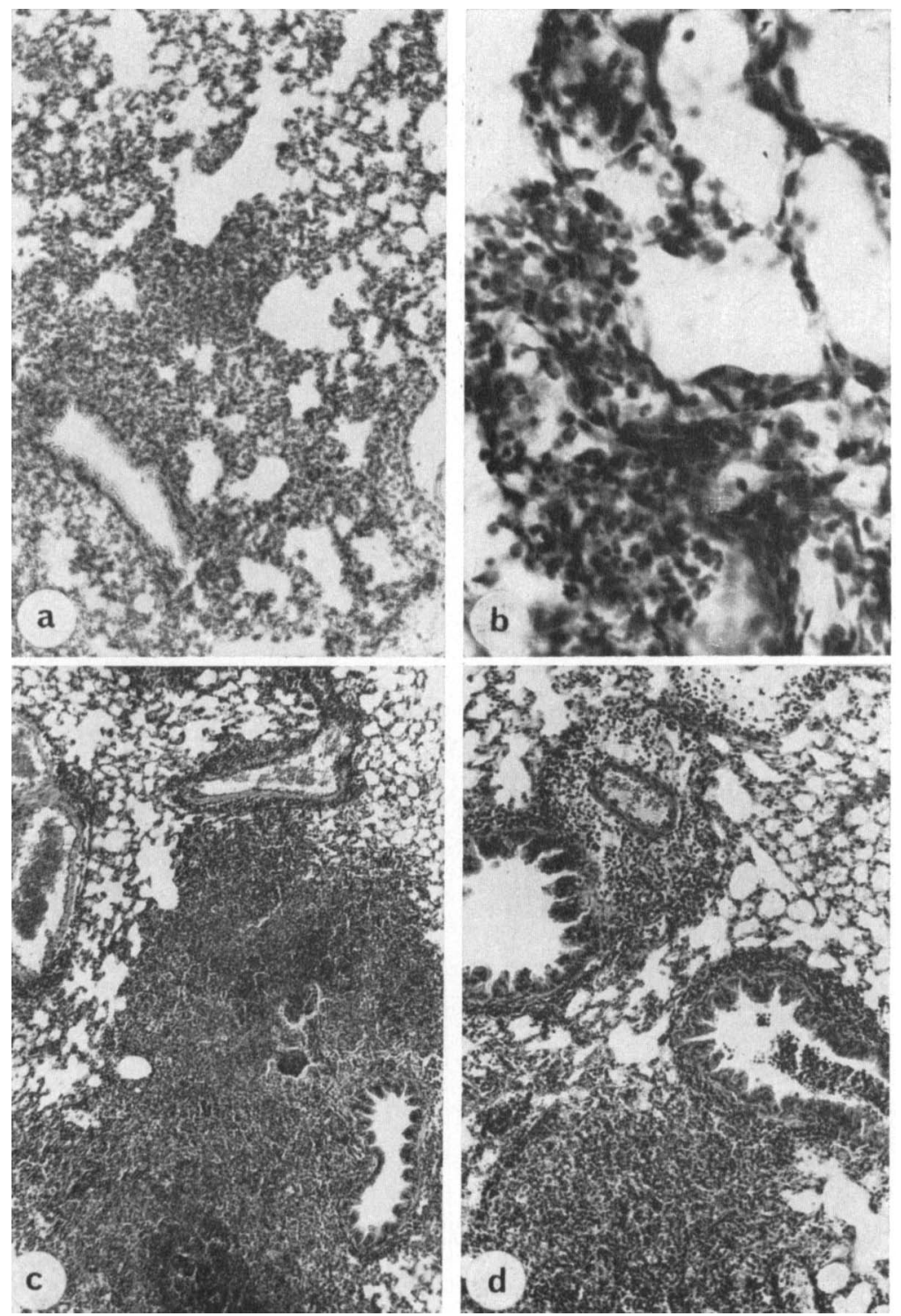

FIG. 4 ( $a, b, c$ and $d$ ).-Infiltration of alveolar septa by inflammatory cells. Haematoxylin and eosin. $\times 126(a)$ and $\times 800(b)$; peribronchiolitis, perivasculitis and granuloma-like areas $(c$ and $d$ ). HE. $\times 126$. 

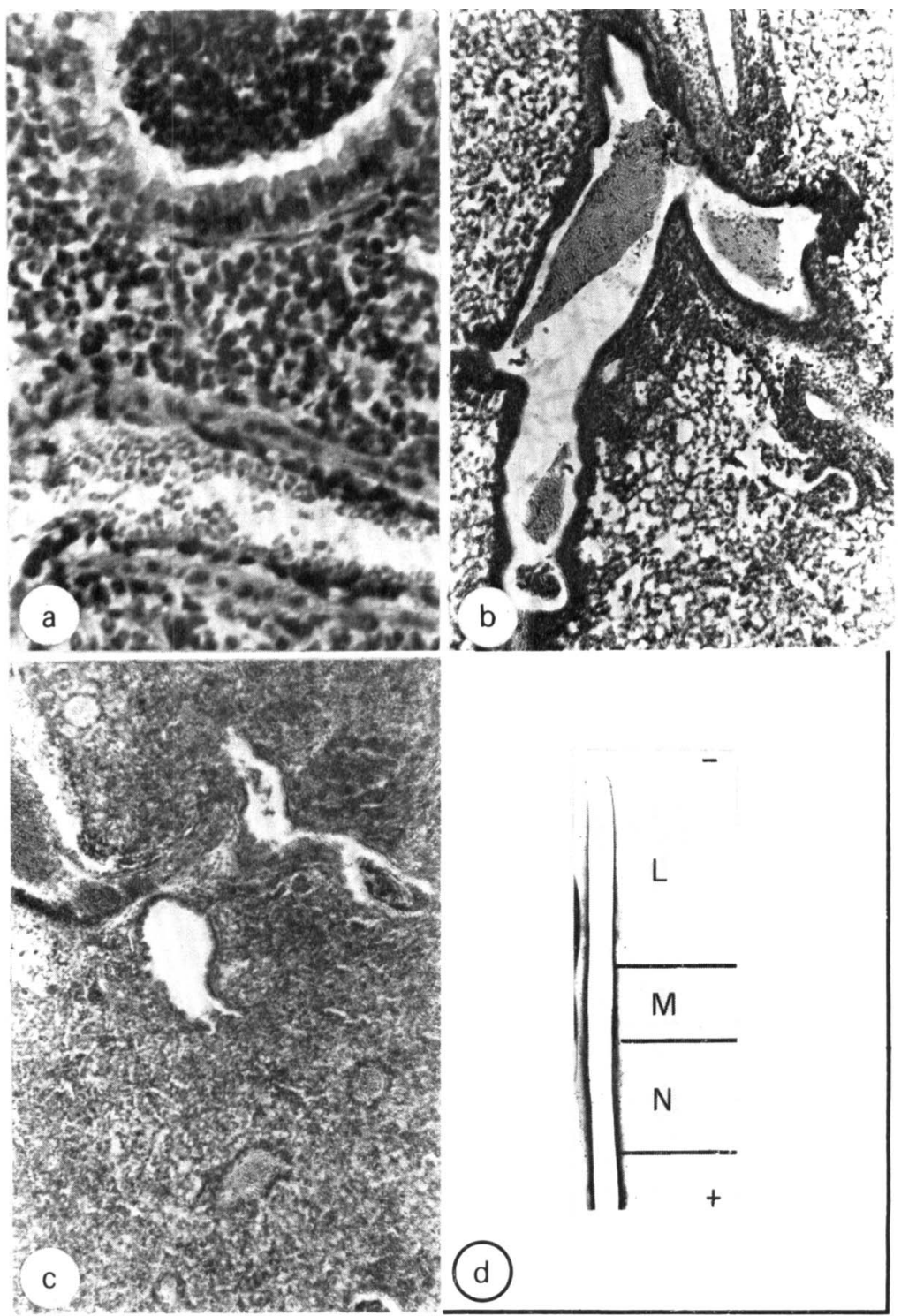

FIG. $5(a, b, c$ and $d)$.- (a) Peribronchiolitis, perivasculitis and filling of the lumen of the bronchiole by inflammatory cells. HE. $\times 800$. (b) Plugs of mucus with inflammatory cells in lumina of bronchioles. HE. $\times 200$. (c) Widespread haemorrhage of lung parenchyma on infiltration of polymorphonuclear leucocytes. HE. $\times 126$. (d) Precipitin arcs obtained in immunoelectrophoresis of polyacrylamide fraction 11 to 50 and human composite antiserum. 
TABLE II

Lesions produced in precipitin-positive mice given a booster dose of TWSE and inoculated intranasally with extracts of $M$. faeni

\begin{tabular}{|c|c|c|c|c|}
\hline \multirow{2}{*}{$\begin{array}{l}\text { Nature of fractions used for } \\
\text { intranasal inoculation }\end{array}$} & \multicolumn{3}{|c|}{ Severity of the three types of lesion } & \multirow{2}{*}{$\begin{array}{l}\text { Reaction in } \\
\text { immunodiffusion }\end{array}$} \\
\hline & A & B & $\mathrm{V}$ & \\
\hline \multicolumn{5}{|l|}{ Immunoadsorbent columns } \\
\hline $3.0 \mathrm{~m}$ acetic acid $\left\{\begin{array}{r}\text { FLD } \\
\text { non-FLD }\end{array}\right.$ & \pm & \pm & $1+$ & $\begin{array}{l}+ \\
+\end{array}$ \\
\hline $6.0 \mathrm{~m}$ guanidine- $\mathrm{HCl}\left\{\begin{array}{r}\text { FLD } \\
\text { non-FLD }\end{array}\right.$ & $\begin{array}{l}3+ \\
1+\end{array}$ & $1 \stackrel{ \pm}{+}$ & $1 \stackrel{ \pm}{+}$ & $\begin{array}{l}+ \\
+\end{array}$ \\
\hline $50 \mathrm{~mm}$ borate $\quad\left\{\begin{array}{r}\text { FLD } \\
\text { non-FLD }\end{array}\right.$ & $\underline{-}$ & - & $\overline{-}$ & $\underline{-}$ \\
\hline $\begin{array}{l}\text { Con A-Sepharose 4B column } \\
\text { (Fraction II) }\end{array}$ & $2+$ & $1+$ & $1+$ & + \\
\hline $\begin{array}{l}\text { Preparative electrophoresis in } \\
\text { agar } \\
\text { Fraction L } \\
\text { Fraction M } \\
\text { Fraction N }\end{array}$ & $\begin{array}{r}2+ \\
\pm \\
\end{array}$ & $\begin{array}{r}2+ \\
\pm\end{array}$ & $\begin{array}{l}2+ \\
1+ \\
-\end{array}$ & $\begin{array}{l}+ \\
+ \\
+\end{array}$ \\
\hline
\end{tabular}

Footnotes as in table $\mathbf{l}$.

Effect of fractions from affinity chromatography: immunoadsorbents. The results summarised in table 2 show that alveolitis and, to a lesser extent, perivasculitis, were provoked by intranasal inoculation with material eluted from both FLD and non-FLD immunoadsorbent columns by $6 \cdot 0 \mathrm{M}$ guanidine- $\mathrm{HCl}$. Other than the mild alveolitis and perivasculitis and minimal peribronchiolitis provoked by the acetic acid fraction from the FLD column, substances eluted by $3 \cdot 0 \mathrm{M}$ acetic acid and $50 \mathrm{~mm}$ borate buffer, $p \mathrm{H} 8 \cdot 0$, were ineffective.

Effect of fractions from preparative agar electrophoresis. Fraction $\mathrm{L}$ produced overall perivasculitis and peribronchiolitis (table II) with frequent granuloma-like areas of alveolitis where alveoli were infiltrated with an exudate in which macrophages predominated. In the alveolar septa both macrophages and polymorphonuclear leucocytes were equally common. Fraction $\mathbf{M}$ caused the development of a few small foci of alveolar filling with little septal infiltration of the surrounding parenchyma. Peribronchiolitis was rare and perivasculitis mild. No effect was observed in the lungs of mice treated with Fraction N.

\section{Immunological lung damage in precipitin-negative mice}

Effect of particulate and crude soluble antigens. In non-immunised animals, intranasal inoculations of LSM, DSM and DFSM produced no reaction in lung tissue. Minimal, sporadic lesions occurred when TWSE was used. Following immunisation for 8 days with TWSE in FCA, intranasal inoculation of TWSE and LSM produced both alveolitis and perivasculitis (table I). 
TABLE III

The effect of fractions from $M$. faeni on the development of bentonite granulomata in the lungs of precipitin-negative, sensitised mice compared with those in unsensitised controls

\begin{tabular}{|c|c|c|c|}
\hline \multirow{2}{*}{$\begin{array}{l}\text { Materials used to coat } \\
\text { bentonite particles }\end{array}$} & \multicolumn{2}{|c|}{$\begin{array}{l}\text { Mean diameter }(\mu \mathrm{m}) \text { of granulomata in } \\
\text { mice that were }\end{array}$} & \multirow{2}{*}{$\begin{array}{l}\text { Degree of alveolitis } \\
\text { produced in precipitin- } \\
\text { positive mice }\end{array}$} \\
\hline & $\begin{array}{l}\text { unsensitised, having } \\
\text { been treated with } \\
\text { saline in FCA }\end{array}$ & $\begin{array}{l}\text { sensitised, having } \\
\text { been treated with } \\
\text { TWSE in FCA }\end{array}$ & \\
\hline Saline & 50.55 & 65.66 & - \\
\hline TWSE & $81 \cdot 55$ & $114 \cdot 38$ & $1+$ \\
\hline $\begin{array}{l}\text { Immunoadsorbent } \\
\text { column fractions } \\
6 \cdot 0 \mathrm{M} \text { guan- }\left\{\begin{array}{r}\text { FLD } \\
\text { idine-HCl } \\
\text { non-FLD }\end{array}\right.\end{array}$ & $\begin{array}{l}\cdots \\
\cdots\end{array}$ & $\begin{array}{r}75 \cdot 43 \\
110 \cdot 75\end{array}$ & $3+$ \\
\hline $\begin{array}{l}\text { Con A-Sepharose } \\
\text { fraction } \\
\text { Fraction II }\end{array}$ & $\ldots$ & $78 \cdot 84$ & $2+$ \\
\hline $\begin{array}{c}\text { Polyacrylamide } \\
\text { fractions } \\
11 \text { to } 18 \\
19 \text { to } 35 \\
36 \text { to } 50\end{array}$ & $\begin{array}{l}\cdots \\
\cdots \\
\cdots\end{array}$ & $\begin{array}{r}92 \cdot 06 \\
113 \cdot 15 \\
81 \cdot 11\end{array}$ & $\begin{array}{l}2+ \\
3+ \\
2+\end{array}$ \\
\hline
\end{tabular}

Footnotes as in table I.

TWSE was the more effective preparation in producing symptoms of disease. DFSM provoked perivasculitis but only small foci of mild alveolitis occurred in lung parenchyma. Chl had no effect, but EE produced minimal perivasculitis and alveolitis.

The bentonite granuloma test. Table III shows that the mean diameters of granulomata induced by bentonite particles coated with TWSE in animals previously sensitised with TWSE in FCA exceeded those produced in unsensitised animals. Of the three extracts producing high values for mean diameter of granulomata ( $>110 \mu \mathrm{m}$ ), only one (polyacrylamide fraction 19 to 35 ) produced severe alveolitis in the precipitin-positive mouse, and the other two (TWSE and the non-FLD guanidine-HCl fraction) produced mild alveolitis. The three fractions producing moderate alveolitis caused the formation of granulomata with mean diameters of between $78 \mu \mathrm{m}$ and $93 \mu \mathrm{m}$ but the FLD guanidine- $\mathrm{HCl}$ fraction, although giving a mean diameter of only $75 \mu \mathrm{m}$ in this test, induced severe alveolitis. Mean diameters of granulomata, therefore, did not correlate directly with the degree of alveolitis induced by the extracts.

Cutaneous reactions were bimodal. In unsensitised mice, a few polymorphs were seen at the site of inoculation after $6 \mathrm{~h}$, and by $15 \mathrm{~h}$ necrosis of adjacent musculature had begun. Increased areas of necrosis with polymorph aggregates were still present at $65 \mathrm{~h}$. In sensitised animals, a severe oedematous phase with a generalised polymorph infiltration was well established by $6 \mathrm{~h}$ and had 


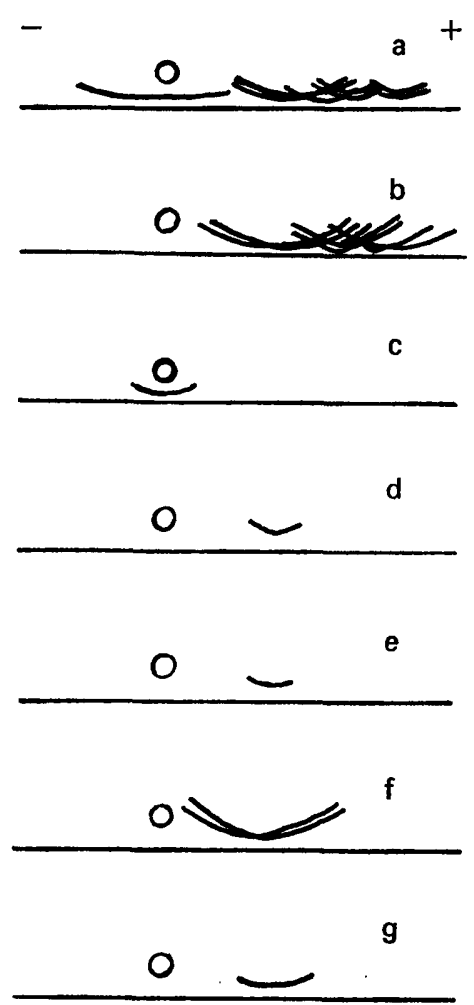

FIG. 6.-Precipitin arcs obtained in immunoelectrophoresis of extracts of $\boldsymbol{M}$. faeni with human composite antiserum. $a=$ Composite culture filtrates; $b=$ polyacrylamide fraction 11 to 50 ; $c=$ fraction desorbed from Con A-Sepharose; $d$ and $e=$ fractions desorbed from FLD and non-FLD immunoadsorbents by $3.0 \mathrm{M}$ acetic acid and $6.0 \mathrm{M}$ guanidine- $\mathrm{HCl}$, respectively; $\mathrm{f}$ and $\mathrm{g}=$ fractions desorbed from FLD and non-FLD immunoadsorbents respectively by $3 \cdot 0 \mathrm{M}$ acetic acid.

subsided substantially by $15 \mathrm{~h}$. At $65 \mathrm{~h}$, however, a nodular delayed type of reaction was characterised by the presence of an almost exclusively mononuclear cell infiltrate.

Antigenicity of fractions in relation to the induction of experimental pulmonary disease. Although all five polyacrylamide fractions used for the intranasal inoculation of mice were precipitinogenic, only three induced alveolitis. These three were combined and, together with all alveolitis-inducing fractions, were assessed by immunoelectrophoresis with human antiserum to $M$. faeni and compared with the original composite culture filtrate of the organism and the fractions of it eluted from human immunoadsorbent columns by $3 \cdot 0 \mathrm{M}$ acetic acid (fig. 6). Four groups of antigens, similar to those described by Edwards (1971 and 1972), were identified in the original culture filtrate. Following separation of the combined tube fractions 11 to 50 from polyacrylamide gel by preparative electrophoresis in agar, groups 2, 3 and 4 were found to be present in fractions $\mathrm{L}, \mathrm{M}$ and $\mathrm{N}$, respectively (figs. $5 d$ and 6). Fractions $\mathrm{M}$ and $\mathrm{N}$, containing the precipitinogens of groups 3 and 4 (region $B$ of Pepys and Jenkins, 1965), did not provoke disease. Fraction L, like the fractions eluted 
from immunoadsorbent columns by guanidine- $\mathrm{HCl}$, induced disease and contained antigens of group 2. Fractions eluted from immunoadsorbent columns by $3.0 \mathrm{M}$ acetic acid also precipitated in region 2 . The FLD acetic acid fraction, although forming particularly strong arcs of precipitation, induced minimal alveolitis and the non-FLD acetic acid fraction, which gave a weak arc of precipitation, did not provoke disease.

Edwards (1972) identified one major and three minor antigens in group 2 (region A of Pepys and Jenkins, 1965). Three antigens of group 2 have been found in culture filtrates during the present work (fig. 6) and two have been identified in material eluted by $3.0 \mathrm{M}$ acetic acid from the FLD immunoadsorbent column. A single group 2 antigen, or part of one, was desorbed by guanidine$\mathrm{HCl}$ from both FLD and non-FLD columns. The alveolitis-inducing Fraction II eluted from Con A-Sepharose by $\alpha$-methyl-D-glucopyranoside precipitated as a group 1 antigen of Edwards (1972), in the C region of Pepys and Jenkins (1965). The ethanol-ether fraction obtained by the defatting of spores and mycelium was serologically inert when tested by double diffusion and immunoelectrophoresis, but provoked moderate alveolitis.

\section{Discussion}

Barrowcliff and Arblaster (1968), reporting an early acute, fatal case of farmer's lung, regarded the underlying hypersensitivity reaction to be of the Arthus (Type III) variety. The lung parenchyma showed many areas of acute inflammatory cell infiltration and haemorrhage. The most acute reaction described in the present work (fig. 5c) involved the development of areas of haemorrhage accompanied by mass infiltration by polymorphonuclear leucocytes in lung tissue showing severe perivasculitis and peribronchiolitis. The reaction, a response to either soluble or particulate antigens in precipitinpositive mice, is also characteristic of Arthus type. It is dependent on the formation of immune complexes between antigen and circulating antibody which fix complement. The formation of chemotactic complement components results in the attraction of polymorphonuclear leucocytes, which after engulfing immune complexes, release the lysosomal enzymes responsible for tissue damage.

The most common features of experimental disease in precipitin-positive mice, however, were infiltration of alveolar septa, predominantly by lymphocytes and macrophages, and the development of granuloma-like areas in the lung (fig. $4 c$ and $d$ ). Such features are strongly suggestive of a Type IV hypersensitivity reaction, and have been noted by Seal et al. (1968) in a review of the pathology of acute and chronic cases of farmer's lung. The Type IV reaction is based upon the antigen-specific activation of T-lymphocytes causing the release of the many factors (lymphokines) that mediate delayed-type hypersensitivity (DTH). Precipitating, humoral antibody does not participate. It was clear, however, that in the lung reaction in precipitin-positive mice, a predominance of polymorphonuclear leucocytes occurred $6 \mathrm{~h}$ after challenge. In experimentally induced Arthus reactions, a time interval of 3 to $8 \mathrm{~h}$ usually 
occurs between challenge and the development of the reaction in a sensitised animal. By $24 \mathrm{~h}$, however, polymorphonuclear leucocytes were scarce in the mouse lung, and macrophages and lymphocytes were characteristic. This would suggest an allergic alveolitis due to a mixture of components of both Type III and Type IV reactions. Edwards (1974), by means of intratracheal instillation in immunised rabbits showed that both living cells of $M$. faeni and glycopeptide antigens extracted from the organism provoked features of both Type III and Type IV reactions. These reactions were also implicated by Wilkie, Pauli and Gygax (1973) in guinea-pigs challenged with ultrasonicated cells of $M$. faeni after previous immunisation with soluble antigens of the organism. Factors initiating the disease were transferred by passive immunisation with plasma or lymphocytes.

The short 8-day immunisation period employed to produce sensitised, precipitin-negative mice resulted in the development of bimodal cutaneous reactions after intradermal challenge with antigen. Reactions in the skin are known to be difficult to interpret and the use of histological criteria alone is insufficient to determine delayed-type responses with certainty (Gell and Coombs, 1968). The considerable part played by a cell-mediated reaction in the formation of respiratory lesions in the mouse is shown, however, by the development of disease following the administration of TWSE, LSM, DFSM and $\mathrm{EE}$ to immunised precipitin-negative animals. A positive bentonitegranuloma test is also regarded as indicating a cell-mediated response. The results of several such tests are shown in table I. Boros and Warren (1974) have shown that the introduction of uncoated bentonite particles into the microvasculature of the lung results in the development of small foreign-body bead granulomata. The introduction of antigen-coated particles into a sensitised mouse, however, resulted in the formation of large hypersensitivity granulomata of distinctive pathology.

It is of interest to note that no respiratory pathology was recorded following intranasal inoculation of non-immunised mice with a range of particulate and soluble antigens during the present investigation with the exception of TWSE. Zaidi et al. (1971) and Salvaggio et al. (1975) recorded pulmonary interstitial lesions following intratracheal inoculations with cells of $M$. faeni in nonimmunised guinea-pigs and rabbits respectively.

It was found that living or dead spores and mycelium were effective as allergens, particularly in immunised mice that were precipitin-positive, but that the allergenicity could be almost nullified by a process of defatting; ethanolether, but not chloroform extracts caused disease. Hollingdale (1975) established that the Gram-negative mycelial walls of $M$. faeni contained a lipopolysaccharide complex (LPS) yielding extracts containing lipid A after treatment with ethanol-ether. The extracts were non-reactive in immunodiffusion tests and did not absorb antibody from FLD antiserum. The ethanol-ether extract obtained during the present study was similarly serologically inert but was alveolitis-inducing.

The fractionating of culture filtrates, either by electrophoresis in polyacrylamide gel, or by the use of affinity columns, yielded antigenic moieties, 
only some of which induced alveolitis in immunised mice (fig. 1 and table 2). Material desorbed from Con A-Sepharose (Fraction II) was glycoprotein in nature because it reacted positively in the Elson-Morgan reaction and glucoselinked because it was antagonised by $\alpha$-methyl-D-glucopyranoside. Fraction II was the only alveolitis-inducing fraction having antigens of group 1 (Edwards, 1972), precipitating in the $C$ region of Pepys and Jenkins (1965). This is characteristically the region in which glycopeptide antigens react (Edwards, 1972; Hollingdale, 1974; Hollingdale and Murray, 1974). Separations in polyacrylamide gel provided five antigenic fractions, of which three were alveolitis-inducing. The three fractions, if bulked, were shown by immunoelectrophoresis to contain three distinct groups of antigens which reacted against human antiserum. Only one of these groups-that possessing a negative charge and precipitating in the A region of Pepys and Jenkins (1965) or region 2 of Edwards (1971)-produced disease after further separation in agar. Closely related or identical antigens desorbed from immunoadsorbents also precipitated with a similar pattern on immunoelectrophoresis (fig. 6) but only those eluted by $6.0 \mathrm{M}$ guanidine- $\mathrm{HCl}$ provoked alveolitis. This suggests that immunoadsorbent columns can be of great value in selectively extracting alveolitis-inducing antigens from a serologically well-defined group not otherwise involved in the induction of disease. The total yield of antigens from such columns was, however, disappointingly low, an observation shared by Roberts (1974) who used sheep antibody-linked Sepharose for the selection of protein antigens of $M$. faeni.

\section{SUMMARY}

Culture filtrates and total water-soluble extracts (TWSE), including ultrasonication products of Micropolyspora faeni were primarily fractionated by electrophoresis in polyacrylamide gels. Other separations included chromatography with Con A-Separose and human immunoglobulins from sera that contained precipitins to farmer's lung hay (FLH) antigen coupled to Sepharose 4B by the cyanogen-bromide method. Fractions were tested for their effects on the lung by the intranasal inoculation of non-immunised mice and of mice immunised with TWSE in Freund's complete adjuvant to give precipitinnegative and precipitin-positive groups. Particulate antigens of $M$. faeni did not induce respiratory disease in non-immunised mice, but TWSE produced negligible, sporadic lesions. Precipitin-positive mice developed symptoms of extrinsic allergic alveolitis when challenged with particulate antigens consisting of living or dead spores and mycelium of $M$. faeni or with TWSE. Elements of both Type III (Arthus) and Type IV (cell-mediated) hypersensitivities were identified histologically. The allergenicity of spores and mycelium was almost nullified by de-fatting, and activity was retained solely in a serologically inert ethanol-ether extract. Fractionation of soluble antigens produced immunologically-active extracts, only some of which induced clinical disease. Alveolitisinducing glycoprotein antigens obtained from Con A-Sepharose by desorption with $\alpha$-methyl-D-glucopyranoside precipitated in the $\mathrm{C}$ region on immunoelectrophoresis. A disease-provoking group of antigens precipitating in the A 
region was isolated by electrophoresis in agar after primary fractionation in polyacrylamide gel. Antigens desorbed both by $3.0 \mathrm{M}$ acetic acid and $6.0 \mathrm{M}$ guanidine- $\mathrm{HCl}$ from immunoadsorbent columns also precipitated in the A region, but only those desorbed by guanidine- $\mathrm{HCl}$ induced alveolitis.

Most fractions inducing disease in precipitin-positive mice also did so in precipitin-negative, immunised animals. The formation of large hypersensitivity granulomata, indicative of the occurrence of a Type IV cell-mediated response, followed the introduction of bentonite particles coated with reactive fractions into the lung. Mean diameters of the granulomata did not correlate directly with the degree of alveolitis induced by the fractions. Skin reactions were bimodal and showed early Type III and late Type IV histology.

The authors are grateful to Drs I. W. B. Grant, J. T. Boyd, J. W. N. Duerden and L. A. Hardie for assistance in obtaining sera from farming personnel, to Dr P. M. Smith for raising antiserum in the rabbit, to $\mathrm{Mr} \mathbf{J}$. M. Dalrymple for technical assistance with histology and to $\mathrm{Mr}$ W. J. Foster for help with photography. The research was supported by a grant from the Scottish Hospital Endowments Research Trust.

\section{REFERENCES}

Aspberg, K. AND Porath, J. 1970. Group-specific adsorption of glycoproteins. Acta chem. scand., 24, 1839.

BarrowCliff, D. F. AND Arblaster, P. G. 1968. Farmer's lung: a study of an early acute fatal case. Thorax, 23, 490.

Boros, D. L. AND WARREN, K. S. 1970. Delayed hypersensitivity-type granuloma formation and dermal reaction induced and elicited by a soluble factor isolated from Schistosoma mansoni eggs. J. exp. Med., $132,488$.

Boros, D. L. AND WARrEN, K. S. 1973. The bentonite granuloma. Characterization of a model system for infectious and foreign body granulomatous inflammation using soluble mycobacterial, histoplasma and schistosoma antigens. Immunology, 24, 511.

Boros, D. L. AND Warren, K. S. 1974. Models of granulomatous inflammation. Ann. N.Y. Acad. Sci., 221, 331.

Cuntrecasas, P. AND ANFinsen, C. B. 1971. Affinity chromatography. Meth. Enzym., 22, 345.

Edwards, J. H. 1971. The production of farmer's lung antigens. Med. Lab. Technol., 28, 172.

EDwARDS, J. H. 1972. The isolation of antigens associated with farmer's lung. Clin. exp. Immun., 11, 341.

EDwaRDs, J. H. 1974. Experimental immunopathology with specific antigen fractions. In Aspergillosis and farmer's lung in man and animal, edited by R. de Haller and F. Suter, Bern, Stuttgart and Vienna, p. 269.

Edwards, J. H., BaKer, J. T. AND Davies, B. H. 1974. Precipitin test negative farmer's lung - activation of the alternative pathway of complement by mouldy hay dusts. Clin. Allergy, 4, 379.

Fletcher, S. M., Rondle, C. J. M. ANd Murray, I. G. 1970. The extracellular antigens of Micropolyspora faeni: their significance in farmer's lung disease. J. Hyg., Camb., 68, 401.

Gell, P. G. H. AND CoOmbs, R. R. A. 1968. Clinical aspects of immunology, 2nd ed., Oxford.

Grant, I. W. B., Blyth, W., Wardrop, V. E., Gordon, R. M., Pearson, J. C. G. and Mair, A. 1972. Prevalence of farmer's lung in Scotland: a pilot survey. Br. med. J., 1, 530.

Heide, K. AND SCHwick, H. G. 1973. In Handbook of experimental immunology, 2nd ed., edited by D. M. Weir, Oxford, vol. 1, p. 6.2. 
Herbert, W. J. 1973. In Handbook of experimental immunology, 2nd ed., edited by D. M. Weir, Oxford, vol. 3, p. A2.12.

Herbert, D., Phipps, P. J. and Strange, R. E. 1971. In Methods in microbiology, vol. 5B, edited by J. R. Norris and D. W. Ribbons, London and New York, pp. 284, 285.

Hollingdale, M. R. 1974. Antibody responses in patients with farmer's lung disease to antigens from Micropolyspora faeni. J. Hyg., Camb., 72, 79.

Hollingdale, M. R. 1975. Isolation of lipopolysaccharide from the walls of Micropolyspora faeni: chemical composition and serological reactivity. J. gen. Microbiol., 86, 250.

Hollingdale, M. R. AND MuRRay, I. G. 1974. Antibody response in farmer's lung disease. In Aspergillosis and farmer's lung in man and animal, edited by R. de Haller and F. Suter, Bern, Stuttgart and Vienna, p. 280.

JoNASSON, O. AND BECKER, E. L. 1966. Release of kallikrein from guinea pig lung during anaphylaxis. J. exp. Med., 123, 509.

KENNEDY, J. F. AND ROSEVEAR, A. 1973. An assessment of the fractionation of carbohydrates on Concanavalin A-Sepharose 4B by affinity chromatography. J. chem. Soc., Perkin Trans. I, 2041.

MolenaAR, J. L., Müller, M. ANd Pondman, K. W. 1973. A new preparative method for isolation of human C3 with affinity chromatography. J. Immun., 110, 1570.

Moore, S. AND SteIN, W. H. 1948. Photometric ninhydrin method for use in the chromatography of amino acids. J. biol. Chem., 176, 367.

Pepys, J. And Jenkins, P. A. 1965. Precipitin (FLH) test in farmer's lung. Thorax, 20, 21.

Pepys, J., Jenkins, P. A., Festenstein, G. N., Gregory, P. H., Lacey, M. E. and Skinner, F. A. 1963. Farmer's lung. Thermophilic actinomycetes as a source of " farmer's lung hay " antigen. Lancet, $2,607$.

RoBERTS, R. C. 1974. Fractionation and chemical characterization studies on Micropolyspora faeni antigens. Ann. N.Y. Acad. Sci., 221, 199.

Salvaggio, J., Phanuphak, P., Stanford, R., Bice, D. and Claman, H. 1975. Experimental production of granulomatous pneumonitis. J. Allergy clin. Immun., 56, 364.

SCHeIDEgGer, J. J. 1955. Une micro-méthode de l'immuno-électrophorèse. Int. Archs Allergy, 7, 103.

Seal, R. M. E., Hapke, E. J., Thomas, G. O., Meek, J. C. and Hayes, M. 1968. The pathology of the acute and chronic stages of farmer's lung. Thorax, 23, 469.

WILKIE, B., PAUl, B. AND GYGaX, M. 1973. Hypersensitivity pneumonitis; experimental production in guinea pigs with antigens of Micropolyspora faeni. Pathologia Microbiol., 39, 393.

Zaidi, S. H., Dogra, R. K. S., Shanker, R. And Chandra, S. V. 1971. Experimental farmer's lung in guinea-pigs. J. Path., 105, 41. 